\title{
Safeguarding children who are exposed to Abuse Linked to Faith or Belief
}

\begin{abstract}
Cases of Child Abuse Linked to Faith or Belief (CALFB) continue to be documented. However, there is limited research and understanding of CALFB. Further, there is a lack of clarity of definition. These factors then impact upon effective practice. Recognising this, the national working group for CALFB called for research on which to develop evidence-based practice. This paper reports on key findings from a mixedmethod online survey which was completed by 1361 participants from a range of practitioner and community groups. The participants identified the importance of policy and multiagency working in this area but they acknowledged the complexity and challenges associated with developing and implementing good practice.

Recommendations from the study include a review of relevant policy to evaluate its application to CALFB, the development of faith literacy training for frontline practitioners and the creation of a space in which statutory, faith and community groups can dialogue.
\end{abstract}

\section{Key Practitioner Messages}

- Frontline workers express a lack of understanding and experience of Child Abuse Linked to Faith or Belief (CALFB) and all require specific training.

- There is a need for Faith Literacy training and a space for statutory and faithbased communities to dialogue to build trust, formulate policy and share good practice.

- Policy around CALFB needs to be formulated and translated into practice.

\section{Key words}

Child abuse, Child protection, Faith groups, Mulitagency working, Procedures/guidelines

\section{Background}

Historically, but not exclusively, Child Abuse Linked to Faith or Belief (CALFB) has been linked to discourse around witchcraft, spirit possession, ritualistic and satanic abuse. The label of 'witch' has been attributed to an individual who is considered to possess 'evil power to harm others' (Stobart, 2006, p. 5) and 'spirit possession' relates to the perception that 'an evil force has entered a child and is controlling him/her to harm others' (Stobart, 2006, p. 5). Accusations of witchcraft or spirit possession in a child have often been linked to negative life events such as illness and unemployment, 
with children being held 'responsible' for events because of spirit possession (Stobart, 2006) or being a witch (Foxcroft, 2012). Accusations may be directed at children who may be noticeably 'different'; being disobedient, or disabled or bedwetting (Goddard, 2012; Stobart, 2006). Following an accusation, a child will often be isolated, confined to home and s/he may undergo exorcisms or even be abandoned. As Stobart (2006, pp. 21-22) notes:

\footnotetext{
“Abuse may also include beating, burning, cutting, semi-strangulation, starving, bath sleeping, being kept away from school, being tied up, asking for the child to be removed, threat of abandonment and neglect; with neglect of these children including failure to provide appropriate medical care, lack of supervision, poor hygiene and nutrition, poor clothing and a lack of a safe environment.'
}

All of these factors increase the child's vulnerability (Foxcroft, 2012).

It should be noted that although traditionally CALFB has been defined in relation to witchcraft and spirit possession it can include a much broader set of harmful practices. For example, there are recorded cases of medical neglect and excessive physical punishment of children being linked to faith or belief (Bottoms et al., 2004; Peters, 2008). Certainly, the requirement for parental consent can sometimes be overridden in cases of a parent wanting to withhold medical treatment due to faith or belief if this is not considered to be in the best interest of the child; though these cases are deeply complex and often demand dialogue and intervention by many different professionals (Brierley et al., 2013).

In September 2017 there was a United Nations (UN) experts workshop on witchcraft and human rights calling for a UN resolution preventing harm to children associated with accusations of witchcraft and calling for a single shared definition of CALFB. In the UK the topic has been raised in public consciousness through high profile cases such as Victoria Climbié and Kristy Bamu (Bartholomew, 2015; Prospera, 2014) and this increased awareness of CALFB is demonstrated in the following government reports: Safeguarding children from abuse linked to a belief in Spirit Possession (HMGov, 2007) and Working together to safeguard children (HM Government, 2006), with the 2018 draft version, on which consultation has now closed, (HM Government, 2018) containing a link to the National Action Plan on CALFB (NAPCALFB) (Department for Education, 2012). Further, a specific category of CALFB was included in the Characteristics of children in need' figures for the first time in 2016-17 (DfE, 2017). CALFB is also referred to in some faith communities' child safeguarding policies and within some child safeguarding training (see for example, Church of England, 2010). This last point resonates with the increased focus on safeguarding in faith communities and is demonstrated also in the growing number of safeguarding posts therein. 
Yet, despite this increased awareness both globally and in the UK, currently there is no universally agreed definition of CALFB and thus the term remains 'open to multiple interpretations' Simon et al. (2012, p. 5). Additionally, there is limited reference to CALFB in academic or practice journals and thus, there are few resources to which practitioners and members of faith and community groups might refer for guidance.

Indeed, even recent media presentations of the story of the abuse perpetrated against Victoria Climbié (The Reunion, 2017) merged discussion of her story with other cases of child abuse which were unrelated to faith or belief. As a consequence, the relevance of faith or belief to the perpetration of the abuse and ultimate death of Victoria Climbie was submerged within the general horror of the experience of the child. Further, as the relevance of multiagency working in CALFB was not discussed, potential debate around the importance of different professions working collaboratively was lost.

In another example, a recent case of CALFB led to criminal convictions in 2017, but this story has failed to be reported in the national press (Leeds, 2016). This is illustrative of the continued silence leading to limited public awareness and dialogue. It is interesting to note the current challenges of working with CALFB, considering that this is by no means a recent safeguarding issue. Rather, faith and belief have been linked throughout history to physical, psychological and emotional abuse of children (Capp, 1995). CALFB is not specific to any given culture or faith (Capp, 1995) with examples being recorded '....worldwide among Europeans, Africans, Asians and elsewhere as well as in Christian, Muslim, Hindu and pagan faiths among others' (Department for Education, 2012, p. 3).

The complexity of cases and issues related to CALFB argues for the necessity of multiagency response. The focus on multiagency working (e.g. Carter et al., 2007; HM Government, 2015; Munro, 2011) has emphasised the need for agencies to work together to most effectively challenge child abuse. However, as Peckover and Golding (2017) note, multiagency working is complex. Clarity around effective sharing of communication and information in a context of different professional roles and responsibilities is essential (Moran et al., 2007; Reder and Duncan, 2004), as is an understanding about how professionals interact and work collaboratively (Hall et al., 2010; White and Featherstone, 2005). Specifically, in working with CALFB there are useful examples of multiagency responses in the Trust for London (2010) work which created the Safeguarding Children's Rights initiative. The formation of the National Working Group (NWG) (https://vcf-uk.org/national-working-group-child-abuse-linked-faithbelief/) also reflects a multiagency response of statutory, voluntary, community and faith organisations. The NWG developed the National Action Plan to tackle child abuse linked to faith or belief in 2012 (Department for Education, 2012). This policy document focuses upon four areas: the need to engage communities; empowering practitioners; supporting victims and witnesses; and communicating key messages. A 
series of activities designed to achieve these aims is listed in the plan. Some of these activities specify the need for research with practitioners and communities and faith leaders and to develop more effective responses to cases of CALFB. Currently, there remains a paucity of work on CALFB, which researches the implementation of these four areas in practice. Additionally, there is very limited work that explores the efficacy of multiagency working or frontline practitioners' knowledge or training needs in [CALFB]'] the area. A focus on these areas could be argued to be essential if victims and witnesses are to be supported more effectively. Understanding the perspectives, knowledge and awareness of frontline practitioners and community groups about CALFB could help to identify knowledge gaps, training needs and practice challenges. Addressing these could then lead to more informed practice and in turn more effective support for witnesses and victims.

The lack of empirical evidence on which to base effective practice was noted by the NWG. The group also acknowledged problems with ascertaining prevalence levels of CALFB. The current study reported in this paper is a result of a joint meeting between the researchers and representatives from the NWG. A general remit of contributing to the limited research and to begin to develop an understanding of frontline professionals and community groups' work around CALFB, including any multiagency working, was identified. The need to record the prevalence of CALFB across communities was also acknowledged; though it was noted that establishing current understandings and knowledge of CALFB in frontline practitioners and community groups needed to be part of the initial focus, as unless individuals understand what constitutes CALFB, and are aware of indicators, any prevalence data will be open to question.

\section{The Study}

The aims of the study were to 1) explore frontline practitioner and community group awareness, understanding and experience of CALFB within their current practice, and 2) identify additional support and training requirements for effective practice. The study was delivered via an online survey using SurveyMonkey. A mixed methods approach (Cresswell and Plano Clark, 2011) was employed. The survey comprised of 21 questions, 13 closed questions and eight open questions. The survey was live from September 2015 to June 2016. In total 1361 people completed the online survey Participants had backgrounds in social work $(n=91)$, teaching $(n=156)$, counselling $(n=79)$, police $(n=318)$, medicine and health care $(n=60)$, faith organisations $(n=771)$ and community organisations ( $\mathrm{n}=143)$ with 219 people listing 'other' as their professional background. The link to the survey was distributed across the internet via membership organisations of the $N W G$ and via social media (Twitter and Facebook). British Psychological Society (BPS) ethical guidelines (BPS,2009) were adhered to and the study was approved by Manchester Metropolitan University ethics 
committee. BPS ethical guidelines require researchers to consider potential harm to participants, anonymity and transparency in research. In order to protect participants and being cognisant of the sensitive nature of the topic the researchers sought to preserve participants' anonymity. Therefore, no IP addresses were collected. The survey began with an information sheet and electronic consent. Participants were not asked about individual cases or personal experiences of CALFB. All identifying information was removed prior to analysis. All participants were given the opportunity to withdraw their data and/or permission for anonymised quotes.

A Likert scale of responses was used to indicate quantitative measures of participants' knowledge, experience and confidence in managing incidences of CALFB. Survey Monkey's online tool was used for descriptive statistical analysis. 'Free text' responses to open questions provided qualitative data on effective practice together with participants' training and support needs. This qualitative data was analysed using Survey Monkey's online qualitative tool.

\section{Findings}

There was a series of closed questions related to understanding and awareness of CALFB. Results of these questions are summarised in Table 1 below.

\begin{tabular}{|l|l|l|l|l|}
\hline Participant & $\begin{array}{l}\text { Had Heard } \\
\text { of term } \\
\text { CALFB }\end{array}$ & $\begin{array}{l}\text { Confident in } \\
\text { knowing what } \\
\text { the term } \\
\text { CALFB } \\
\text { means }\end{array}$ & $\begin{array}{l}\text { Confident in } \\
\text { identifying } \\
\text { Indicators }\end{array}$ & $\begin{array}{l}\text { Confident in } \\
\text { responding } \\
\text { professionally }\end{array}$ \\
\hline Teacher & $73 \%(\mathrm{n}=92)$ & $62 \%(\mathrm{n}=88)$ & $35 \%(\mathrm{n}=39)$ & $55 \%(\mathrm{n}=65)$ \\
\hline Social Worker & $93 \%(\mathrm{n}=58)$ & $85 \%(\mathrm{n}=50)$ & $59 \%(\mathrm{n}=37)$ & $72 \%(\mathrm{n}=45)$ \\
\hline $\begin{array}{l}\text { Medical/health } \\
\text { care } \\
\text { Professionals }\end{array}$ & $73 \%(\mathrm{n}=24)$ & $49 \%(\mathrm{n}=16)$ & $36 \%(\mathrm{n}=11)$ & $57 \%(\mathrm{n}=17)$ \\
\hline $\begin{array}{l}\text { Member of a } \\
\text { faith } \\
\text { organisation }\end{array}$ & $76 \%(\mathrm{n}=444)$ & $71 \%(\mathrm{n}=356)$ & $33 \%(\mathrm{n}=180)$ & $53 \%(\mathrm{n}=290)$ \\
\hline $\begin{array}{l}\text { Member of a } \\
\text { community } \\
\text { organisation }\end{array}$ & $79 \%(\mathrm{n}=89)$ & $67 \%(\mathrm{n}=78)$ & $39 \%(\mathrm{n}=44)$ & $55 \%(\mathrm{n}=66)$ \\
\hline Police & $72 \%(\mathrm{n}=153)$ & $55 \%(\mathrm{n}=119)$ & $35 \%(\mathrm{n}=71)$ & $49 \%(\mathrm{n}=99)$ \\
\hline Counsellor & $77 \%(\mathrm{n}=48)$ & $65 \%(\mathrm{n}=40)$ & $46 \%(\mathrm{n}=28)$ & $55 \%(\mathrm{n}=34)$ \\
\hline
\end{tabular}

Table 1 - Understanding and awareness of CALFB by respondent category 
There was a series of closed questions related to policy and knowledge of the National Action Plan on CALFB (NAPCALFB) and whether the Local Safeguarding Children's Board (LSCB) had policy and procedure related to CALFB. Finally, there was a question identifying additional support for working in this area. The results are summarised in Table 2 below.

\begin{tabular}{|l|l|l|l|}
\hline Participant & $\begin{array}{l}\text { Familiar with } \\
\text { NAPCALFB }\end{array}$ & $\begin{array}{l}\text { \% who stated that } \\
\text { their LSCB include } \\
\text { policies and } \\
\text { procedures around } \\
\text { CALFB }\end{array}$ & $\begin{array}{l}\text { Request for } \\
\text { additional support } \\
\text { in working with } \\
\text { CALFB }\end{array}$ \\
\hline Teacher & $13 \%(\mathrm{n}=15)$ & $20 \%(\mathrm{n}=23)$ & $78 \%(\mathrm{n}=88)$ \\
\hline Social Worker & $32 \%(\mathrm{n}=20)$ & $25 \%(\mathrm{n}=15)$ & $67 \%(\mathrm{n}=41)$ \\
\hline Medical Practitioner & $14 \%(\mathrm{n}=4)$ & $14 \% \%(\mathrm{n}=4)$ & $75 \%(\mathrm{n}=21)$ \\
\hline $\begin{array}{l}\text { Member of a faith } \\
\text { organisation }\end{array}$ & $13 \%(\mathrm{n}=67)$ & $17 \%(\mathrm{n}=91)$ & $67 \%(\mathrm{n}=354)$ \\
\hline $\begin{array}{l}\text { Member of a } \\
\text { community } \\
\text { organisation }\end{array}$ & $15 \%(\mathrm{n}=16)$ & $24 \%(\mathrm{n}=24)$ & $70 \%(\mathrm{n}=75)$ \\
\hline Police & $6 \%(\mathrm{n}=12)$ & $11 \%(\mathrm{n}=22)$ & $66 \%(\mathrm{n}=131)$ \\
\hline Counsellor & $11 \%(\mathrm{n}=6)$ & $19 \%(\mathrm{n}=12)$ & $74 \%(\mathrm{n}=45)$ \\
\hline
\end{tabular}

Table 2 - Awareness of policy and procedures and request for additional support by respondent category

Responses indicate two key challenges for effective working with CALFB in the open text comments. These were identified as 'policy' and 'multiagency working'. The research findings illustrate that participants were working with broad understandings of CALFB. Excessive physical punishment, medical neglect and FGM were all listed in the open text responses asking for a definition. For a detailed discussion on the issues of the definition and understanding of CALFB, (Oakley, Kinmond, Humphreys \& Dioum, 2017).

Policy

Knowledge about the NAPCALFB was very low across all responses with almost 90 per cent participants stating that they had no knowledge of this plan. Six per cent of all participants did not know whether their LSCB included policy or practice around CALFB.

Thirty-four open text comments included policy as part of an effective response to CALFB. The emphasis was on the need for rigorous policy that incorporates faith and abuse: 
'Policies and procedures that take abuse linked to faith seriously and enable robust investigation alongside the statutory requirement to report concerns to the LADO [Local Authority Designated Officer].'

Participants also recognised the importance of faith communities developing their own policy for working with CALFB: 'Good safeguarding policies and practices within faith communities'. The need for open discussion of CALFB within policy was emphasised:

'A transparent policy making it clear that it will not be tolerated, open discussion about the possibility of it happening in any given faith community.'

However, in other questions, the issue of policy seemed to divide participants with some suggesting that the signs of abuse in statutory documents such as Working Together (HM Government, 2015) were comprehensive and applicable to CALFB: 'Working Together provides an exhaustive summary of signs of abuse'. Conversely, others seemed less confident that this policy was effective:

'The whole area of 'spiritual' abuse in its widest form is not accepted as one of the areas identified in Working Together. Many secular professionals are resistant to the concept, making it difficult to address anything other than any visible or identifiable symptoms.'

One participant emphasised the need to lead with policy development and to raise awareness of CALFB at a national and local level if effective response and prevention are to be implemented:

'From policy level down to community level there are all manner of challenges that need to be addressed if this issue is to be addressed effectively. At the moment there is very weak government interest in this issue. The national action plan has been a token gesture that hasn't really led to a great deal of positive change. Finally, at community level, police, social workers, teachers and child protection staff have very little understanding or awareness of these issues. Until some, or all, of these changes it is likely that more cases will continue to arise.'

Some participants suggested the need for support in developing effective policy for CALFB: 'Information on approaching the subject and formulating organisational policy'. Others reflected on the necessity to underpin policy development with training and information about CALFB: 'We cannot put a paragraph in our policy about this subject until we have received appropriate training or collective and agreed information'.

\section{Multiagency working}

Across responses, the necessity for multiagency working in preventing and tackling CALFB was clear: 'Ensure referrals have been made to instigate multi-agency strategy meeting to make decisions around the child' and 'Liaison between faith and statutory 
authorities to secure the welfare of the child'. The requirement to work with leaders of faith communities in addressing CALFB was reflected in some answers: 'Working with faith leaders who understand child protection is useful because they can give faithbased rationales and support within the faith community'. Some participants suggested for multiagency working in this area to be effective additional support may be needed around faith or belief: 'Involvement of advisors to understand particular context/background of faith/belief'.

The challenges to multiagency working were noted in many responses. Some comments reflected a perceived mistrust of statutory agencies by faith communities: 'Indication that secular agencies/authorities are distrusted /avoided'. Others reported negative perceptions from frontline practitioners of any individual holding a faith or belief: 'The perception by colleagues that faith is a sign of stupidity or naivety'. Many participants reported a lack of confidence in working with issues associated with faith and belief: 'The things I do not yet know about are Faith Constructs, particular religions, or belief structures. Working with Faith leadership when there is an identified problem'.

Further challenges to multiagency working were reported in some responses. Many participants stated limited experiences of working with CALFB: 'I have never personally encountered a case of child abuse linked to faith and belief'. Other responses indicated that the cultural background and personal beliefs of frontline practitioners may affect their own response to CALFB_which in turn could have an impact on multiagency working: 'There is also often a difference of opinion between police officers and social workers who may have a cultural background of their own who can see these offences as low level for that reason'.

One participant suggested that the low levels of referrals for CALFB are an indication of the failure of multiagency working in this area: 'The fact that so few cases get directly referred and yet at training sessions it is often raised, suggests that it is happening, but we don't know how to work together as agencies to tackle it'.

\section{Discussion}

The present study illustrates key concerns and challenges to effective policy and practice for CALFB. The findings echo Laming's (2003) recommendations to develop multiagency working. However, they also reinforce the complexities and challenges with implementing such practices raised by Peckover and Golding (2017) together with the need for professionals to interact and work collaboratively (Hall et al., 2010).

A key issue is the need for a single shared definition of CALFB. Certainly, this presents some challenges with much time being devoted to it in the recent UN experts workshop on witchcraft and human rights (UN Expert Workshop, 2017). To date in the UK, the NAPCALFB uses the traditional understanding of CALFB, focusing on witchcraft and spirit possession, though the national working group discussed broadening the remit of 
their work whilst still acknowledging that there remains much work to be done in effectively tackling abuse linked to beliefs in spirit possession and witchcraft (Department of Education, 2012). It is clear from participants' responses to the survey reported here that work in this area must acknowledge and engage with the broad definitions of CALFB used and understood currently. Further work is also needed to analyse the Children in Need census data (DfE, 2017) to explore which behaviours were categorised as CALFB in order to develop a more detailed understanding of the issues impacting children's safeguarding in this area. A data access request has been made to the National Pupil Database to access the Children in Need census data related to CALFB in order to conduct this analysis. Additional useful information might be gathered in future research on a broader range of 'harmful practices', such as FGM and breast ironing, and the interlinking of these with one another. Barnardo's have begun to map some of this data (National working Group for child abuse linked to Faith or Belief, February 2018), for example linking together cases of FGM and CALFB.

The NAPCALFB was published in 2012, but it is evident in the Findings of the current study that there is minimal knowledge of this plan and consequently it is having little influence or impact. Further, the current study has clearly shown that recent policy, such as Working Together (HM Government, 2015) is useful for some professionals but limited in effectiveness for CALFB. It is clear that despite some effective policy being developed, this policy has failed to translate into awareness and practice.

Thus, the first recommendation of the current study is that the NAPCALFB is reviewed and achievable SMART goals are established to aid effective implementation. In order for this strategy to be effective there is significant need for financial and government support. The current position is an absence of funding and government backing. This severely limits the possibilities of actioning any SMART goals proposed. In September 2018 a new All-Party Parliamentary Group for safeguarding in faith communities was formed. The first inquiry for this group will be the topic of child abuse linked to faith or belief. It is hoped that this will lead to a greater focus and investment from government (CCPAS, 2018).

The second recommendation is to review Working Together (HM Government, 2018) to evaluate its focus on safeguarding in faith settings, with particular application to CALFB. It should be noted that the draft 2018 version of Working Together (HM Government, 2018) still only carries a single paragraph addressing issues of safeguarding within a faith context. Between 1999 and 2006, this key statutory guidance increased its recognition of such concerns from a cursory mention of faith settings to almost a page highlighting the importance of the role of those safeguarding in faith contexts. This attention increased in 2010 only to be almost completely omitted by 2013. It is clear therefore, that policy supporting practitioners working alongside issues of faith is minimal and thought must be given to redressing this balance in future editions of Working Together. It is suggested that this review includes revisiting the 
guidance offered in Safeguarding children from abuse linked to a belief in Spirit Possession (HM Government, 2007). The information contained underpins prevention work and advises how to develop effective support for witnesses and victims yet very little of this detailed guidance is reflected in the most recent edition of Working Together (HM Government, 2018).

It should be noted however that some previous initiatives in this area have focused on policy, training and dialogue with witnesses and victims. One such example is Project Violet (Metropolitan Police, 2005) out of which the NAPCALFB was developed. Nevertheless, the research reported in this paper demonstrates that only 12 per cent of participants were aware of the NAPCALFB which suggests that recommendations alone are insufficient. Rather, financial and governmental backing are required if the recommendations are to be implemented.

The findings of the current study also strongly indicate the importance of faith literacy training for frontline practitioners to facilitate effective practice with CALFB. The census figures for CALFB (DfE, 2017) identified 1460 cases in England during 201617. That is four cases a day. These figures may appear small when compared to other forms of abuse such as domestic violence and abuse. However, given the complexities and confusion surrounding CALFB, and the fact that this was the first time the category had been included in the census, it is possible that some cases had been missed. Therefore, the numbers should not be dismissed. Further, there were more recorded cases of CALFB than of FGM. Thus, an argument can be made that to build effective support for victims and witnesses faith literacy training is needed. One suggestion could be that faith literacy training should be targeted at those local education authorities (LEAs) returning cases to the census. However, caution must be taken in this approach. As CALFB is still an emerging topic it is important that training is offered across LEAs as it may be that the census reflects cases identified in authorities where training and awareness is more enhanced.

Faith literacy is a term which has been around for the last twenty years, though it has only recently become common parlance. Arguably, this is a mark of the now widespread recognition of the importance of religion and belief in public consciousness. It is important to note, however, that the notion of religious literacy has now become very current, but also contested. The lack of confidence in working with spirituality and faith identified in the current study is common place. Indeed, Dinham and Francis (2016, p. 4) note that many British people are 'in a muddle' about religion. They argue for the necessity for religious literacy to be developed. To date, it is noticeably absent from teaching curricula, for example Matthews (2009) notes the absence of spirituality and faith from social worker training. However, the development of this knowledge is essential, as Elliott (2017) argues that for many service users their faith and spirituality are deeply central and thus, there is a pressing need to address the gap in understanding of these concepts by service providers. 
Thus, the third recommendation is to develop faith literacy curricula across front line professional training and continuing professional development.

The findings of the current study illustrate a void in understanding and effective working on CALFB across frontline professionals and faith and community groups. A distrust of statutory agencies is demonstrated in some responses from faith communities Similarly, a dismissive attitude towards faith and belief is noted in some professionals' responses. Research undertaken in the field of safeguarding children mirrors these findings suggesting that there has been 'a disconnect between social services and faith communities concerning child abuse prevention efforts' (O'Neill et al., 2010, p. 381). Mistrust can arise in different ways, for example, through lack of information and opportunities to develop partnership working (O'Neill et al., 2010).

However, models of good practice exist which demonstrate the impact of dialogue between statutory and faith agencies in diminishing distrust and building good relationships. One such model came out of Operation Nicole in 2008 (Dinham \& Francis, 2016). The aim of this initiative was to develop relationships between the Muslim community and Police officers in the wake of 7/7 (the 7 July 2005 London bombings). At first facilitated meetings showed a lack of understanding of the Muslim faith in police officers (Dinham \& Francis, 2016). However, through a process called 'Learning From Each Other's Stories' (LEOS) both parties developed mutual understandings and respect and relationships which endured after the events (GriffithsDickinson, 2015 cited in Dinham and Francis, 2016). Dinham and Francis (2016) suggest that such dialogue allows individuals to achieve mutual respect through understanding differences. Such conversations are not an attempt to persuade someone to another's viewpoint but to understand the 'otherness' of someone's opinion and through this to have greater awareness and to build mutual respect.

The fourth recommendation is to create safe spaces for statutory and faith-based communities to dialogue, build trust, formulate policy and share good practice around CALFB. This could be achieved, in part, through CALFB conferences and workshops, with delegates and speakers representing those agencies and communities engaged with safeguarding children.

In conclusion, the results of this survey have shown that professionals and members of faith communities want to address CALFB, but that currently, they lack the skills and knowledge so to do. The survey has also shown that there is a desire for multiagency working in this area. We believe that there is a need for fundamental improvements in the skills acquisition and training of frontline professionals in CALFB. Policy, training and resources are key.

\section{References:}


Bartholomew L. 2015. Child abuse linked to beliefs in witchcraft. Transnational Social Review 5(2): 193-198. https://doi.org/10.1080/21931674.2015.1028809

Bottoms BLB, Nielsen M, Murray R, Filipas H. 2004. Religion-Related Child Physical Abuse. Journal of Aggression, Maltreatment \& Trauma 8(1-2): 87-144.

British Psychological Society. 2009. Code of Ethics and Conduct. Available: https://www.bps.org.uk/sites/bps.org.uk/files/Policy\%20\%20Files/Code\%20of\%20Ethics\%20and\%20Conduct\%20(2009).pdf [Accessed 3 January 2016]

Brierley J, Linthicum J, Petros A. 2013. Should religious beliefs be allowed to stonewall a secular approach to withdrawing and withholding treatment in children? Journal of Medical Ethics 39(9): 573-577. http://dx.doi.org/10.1136/medethics-2011-100104

Capp D. 1995. The child's song: The religious abuse of children. Westminster John Knox Press: Louisville, KY, USA.

Carter B, Cummings J, Cooper L. 2007. An exploration of best practice in multi-agency working and the experiences of families of children with complex health needs. What works well and what needs to be done to improve practice for the future? Journal of Clinical Nursing 163: 527-539. https://doi.org/10.1111/j.13652702.2006.01554.X

Churches Child Protection Advisory Service (CCPAS). 2018. New All-Party Parliamentary Group on Safeguarding in Faith Communities launched. https://ccpasblog.wordpress.com/2018/09/18/new-all-party-parliamentary-group-onsafeguarding-in-faith-settings-launched/ [Accessed on 10 October 2018].

Church of England. 2010. Protecting all God's children. The Policy for Safeguarding Children in the Church of England. Available: https://www.churchofengland.org/sites/default/files/201711/protectingallgodschildren.pdf [2 October 2018].

Cresswell, J.W, Plano Clark, V.L. 2011. Designing and conducting mixed methods research. Sage: London.

Department for Education. 2017. Characteristics of children in need: 2016 to 2017. Available https://assets.publishing.service.gov.uk/government/uploads/system/uploads/attachm ent data/file/656395/SFR61-2017 Main text.pdf [ 3 December 2017]. 
Department of Education. 2012. National Action Plan to Tackle Child Abuse Linked to Faith and Belief. Available:

https://assets.publishing.service.gov.uk/government/uploads/system/uploads/attac hment_data/file/175437/Action_Plan___Abuse_linked_to_Faith_or_Belief.pdf [2 October 2018].

Dinham A, Francis M. 2016. Religious literacy in policy and practice. Policy Press: Bristol.

Elliott N. 2017. Faith, ethics and social work: Framework for an Introductory Lecture. Ethics and Social Welfare 11(1): 92-99. https://doi.org/10.1080/17496535.2017.1287633

Foxcroft G. 2012. Supporting victims of witchcraft abuse and street children in Nigeria. Available: https://www.streetchildren.org/wpcontent/uploads/2013/03/supporting-victims-of-witchcraft-abuse-street-childrennigeria.pdf [2 October 2018].

Goddard C. 2012. Behind closed doors. Available: https://www.cypnow.co.uk/cyp/feature/1071803/behind-closed-doors [2 October 2018].

Hall C, Slembrouck S, Haigh E, Lee A. 2010. The management of professional roles during boundary work in child welfare. International Journal of Social Welfare 19: 348-357. https://doi.org/10.1111/j.1468-2397.2010.00725.x

HM Government. 2006. Working together to safeguard children. The Stationery Office: London.

HM Government. 2007. Safeguarding children from abuse linked to a belief in Spirit Possession. Available:

http://webarchive.nationalarchives.gov.uk/20080610170255/http://www.everychil dmatters.gov.uk/resources-and-practice/IG00220/ [30 September 2018].

HM Government. 2018. Working together to safeguard children: A guide to interagency working to safeguard and promote the welfare of children. The Stationery Office: London.

Laming L. 2003.The Victoria Climbié Inquiry: Report. Available: http://webarchive.nationalarchives.gov.uk/20130401151715/http://www.educatio n.gov.uk/publications/eOrderingDownload/CM-5730PDF.pdf [2 October 2018].

Mathews I. 2009. Social Work and Spirituality. Learning Matters: Exeter. 
https://www.birmingham.ac.uk/generic/tsrc/documents/tsrc/working-papers/workingpaper-137.pdf [2 October 2018].

Metropolitan Police. 2005. Child abuse linked to faith or belief.

https://www.met.police.uk/advice/advice-and-information/caa/child-abuse/faith-basedabuse/ [Accessed on 10 ${ }^{\text {th }}$ October 2018].

Munro E. 2011. The Munro Review of Child Protection: Final Report. A Child-Centred System. Department for Education: London.

Moran P, Jacobs C, Bunn A, Bifulco A. 2007. Multi-agency working: implications for an early intervention social work team. Child and Family Social Work 12:143151. https://doi.org/10.1111/j.1365-2206.2006.00452.x.

National working group for child abuse linked to faith or belief meeting, $5^{\text {th }}$ February 2018. London.

Oakley L, Kinmond K, Humprheys J, Dioum M. (2017). Practitioner and communities' awareness of CALFB: Child abuse linked to faith or belief. Child Abuse and Neglect (72 2017. 276-282)

O'Neill EO, Gabel J, Huckins S, Harder J. 2010. Prevention of Child Abuse and neglect through Church and Social Service Collaboration. Social Work and Christianity 37(4): 381-406.

Peckover S, Golding B. 2017. Domestic Abuse and Safeguarding Children: Critical Issues for Multiagency Work. Child Abuse Review 26(1):40-50. https://doi.org/10.1002/car.2392

Peters SW. 2008. When Prayer Fails. Faith, Healing, Children and the Law. Oxford University Press: New York, NY, USA.

Prospera T. 2014. Witchcraft branding and the abuse of African children in the UK: Causes, effects and professional intervention. Early Child Development and Care 184(9-10): 1403-1414. https://doi.org/10.1080/03004430.2014.901015

Reder P, Duncan S. 2004. Making the most of the Victoria Climbié inquiry report. Child Abuse Review 13(2): 95-114. https://doi.org/10.1002/car.834.

The Reunion. 2017. BBC Radio 4, 30 April. Available:

https://www.bbc.co.uk/programmes/b08njzh0 [28 September 2018].

Simon A, Hauari H, Hollingworth K, Vorhaus J. 2012. A Rapid literature review of evidence on child abuse linked to faith and belief. (CWRC Working Paper No 15).

Childhood and Wellbeing Research Centre: London. 
Stobart E. 2006. Child Abuse Linked to Accusations of "Possession" and "Witchcraft". (Research Report 750). Department for Education and Skills: Nottingham.

Trust for London. 2010. Safeguarding Children's Rights: exploring issues of witchcraft and spirit possession in London's African communities. Available https://www.trustforlondon.org.uk/publications/safeguarding-childrens-rightsexploring-issues-witchcraft-and-spirit-possession-londons-african-communities/ [Accessed January 2015].

United Nations Expert Workshop on Witchcraft and Human Rights. 2017. UN Human Rights Council, Geneva, Sept 21-22, 2017.

White S, Featherstone B. 2005. Communicating misunderstandings: multi-agency work as social practice. Child and Family Social Work 10: 207-216. https://doi.org/10.1111/j.1365-2206.2005.00372.x. 